\title{
Koszty zewnętrzne w transporcie szynowym
}

\begin{abstract}
$W$ artykule przedstawiono zagadnienia zwiqzane z szacowaniem kosztów zewnętrznych $w$ transporcie ze szczególnym uwzględnieniem transportu szynowego. Przedstawiono wybrane wyniki badań wykorzystywanych między innymi przez instytucje europejskie do oceny kosztów zewnętrznych generowanych przez poszczególne gałęzie transportu. Wskazano także na nowe kategorie kosztów zewnętrznych, będace obecnie w obszarze zainteresowania badaczy.
\end{abstract}

\section{Wstęp}

Wykorzystywanie transportu szynowego, zwłaszcza w stosunku do transportu wyłącznie drogowego, wpisuje się w politykę zrównoważonego rozwoju. Wybór gałęzi transportu w kontekście kosztów społecznośrodowiskowych powinien zapewniać ochronę przyrody i jej zasobów np. poprzez akceptowalną emisję substancji szkodliwych czy hałasu, a przy tym zapewnić mobilność społeczeństwa oraz dostawy ładunków po przystępnych cenach, a także w bezpieczny sposób.

Transport drogowy jest gałęzią najbardziej konkurencyjną w realiach polskiej gospodarki. Decydujący wpływ na to ma dostępność usług i poziom cen. Gdyby jednak uwzględnić całokształt oddziaływań, w tym wpływ na środowisko naturalne, zdrowie ludzkie czy generowanie kongestii, transport drogowy traci swoja przewagę konkurencyjną. Jednym ze sposobów pełnej oceny realizacji usług poszczególnymi gałęziami transportu, poza czystą kalkulacją rentowności wynikającej z rachunku ekonomicznego, jest szacowanie kosztów zewnętrznych. Kosztami zewnętrznymi transportu są wszelkie koszty zużycia środków służących do wytworzenia usługi transportowej, które nie są ponoszone przez producenta usługi, ale przez ogół społeczeństwa. Do kosztów zewnętrznych wliczane są koszty związane $\mathrm{z}$ negatywnymi dla środowiska naturalnego i życia człowieka skutkami działalności transportu, do których zalicza się przede wszystkim:

- zanieczyszczenie wody, gleby, powietrza,

- emisję gazów cieplarnianych,

- emisję hałasu,

- wypadki,

- kongestia,

- zajętość terenu i wpływ na zmiany w krajobrazie, w tym zajmowanie cennych przyrodniczo terenów i rozcinanie ich ciagłości (fragmentacja) nowo budowanymi ciagami infrastruktury technicznej, co przyczynia się do utraty różnorodności biologicznej, a także utrudnień w funkcjonowaniu dotkniętych tym oddziaływaniem społeczności.
Szacowanie poziomu kosztów zewnętrznych jest trudne $\mathrm{z}$ uwagi na to, iż otwartym pozostaje sam problem definiowania szkód spowodowanych zniszczeniem środowiska naturalnego. $\mathrm{W}$ wielu przypadkach szkody te nie są dostrzegane natychmiast. Nie zawsze można także z pełnym przekonaniem stwierdzić, że takie czy inne zmiany w przyrodzie lub oddziaływania na zdrowie ludzkie wynikają na pewno $\mathrm{z}$ ingerencji człowieka $\mathrm{w}$ środowisko, a $\mathrm{w}$ szczególności są rezultatem oddziaływań transportu. Co więcej, szkody te często nie są przedmiotem bezpośredniej wymiany rynkowej, a zatem nie są mierzalne bezpośrednio $\mathrm{w}$ wartościach pieniężnych. Wyznaczane muszą być one w oparciu o różnego rodzaju techniki waluacji, jak gotowość do zapłaty, czy też gotowość do akceptacji. W zależności od wykorzystanej techniki, wartości wyceny tychże kosztów mogą się różnić, co rodzi wattpliwości odnośnie poziomu poprawności odwzorowania rzeczywistości przez te narzędzia $[2,3,5]$. Dodatkowo rozwój techniki powoduje zmiany nie tylko o charakterze ilościowym (np. poziom emisji związków toksycznych), ale także o charakterze jakościowym (np. zmiana w strukturze emisji) [7]. Skutkuje to względnie szybką dezaktualizacją prowadzonych w tym zakresie badań. Ponadto koszty różnią się w zależności od konkretnej lokalizacji infrastruktury transportowej oraz gałęzi transportu [2, 5]. Ostatecznie należy zauważyć, iż niektóre spośród wskazanych powyżej kategorii kosztów mogą być częściowo zewnętrzne, a częściowo ponoszone, jako koszty wewnętrzne, przez użytkowników transportu [5].

$\mathrm{W}$ artykule przedstawiono wybrane wyniki badań wykorzystywanych między innymi przez instytucje europejskie do oceny kosztów zewnętrznych generowanych przez poszczególne gałęzie transportu. Wskazano także na nowe kategorie kosztów zewnętrznych, będące obecnie w obszarze zainteresowania badaczy.

\section{Koszty środowiskowe}

Zmniejszenie wykorzystania transportu drogowego oraz przeniesienie przewozów na kolej w dużym stopniu może wpłynąć na zmniejszenie negatywnego 
Tabela 1. Koszty generowane przez czynniki oddziałujące negatywnie na środowisko w różnych gałęziach transportu

\begin{tabular}{|l|c|c|c|c|}
\hline \multicolumn{1}{|c|}{ [euro/1000 tkm] } & $\begin{array}{c}\text { Transport } \\
\text { samochodowy }\end{array}$ & $\begin{array}{c}\text { Transport } \\
\text { kolejowy }\end{array}$ & $\begin{array}{c}\text { Źegluga } \\
\text { śródlądowa }\end{array}$ & $\begin{array}{c}\text { Żegluga bliskiego } \\
\text { zasięgu }\end{array}$ \\
\hline Poziom hałasu & 2,138 & 3,45 & 0 & 0 \\
Emisja zanieczyszczeń & 7,85 & 3,8 & 3 & 2 \\
Emisja gazów cieplarnianych & 0,79 & 0,5 & Nieistotne & Nieistotne \\
Suma & $\mathbf{1 0 , 7 7}$ & $\mathbf{7 , 7 5}$ & około 3 & około 2 \\
\hline
\end{tabular}

Źródto: European Commission, Commission calculation of the external cost savings according to Article 5(3)of the draft Regulation, 2002

Tabela 2. Porównanie negatywnych oddziaływań środowiskowych transportu drogowego, kolejowego i kombinowanego drogowo-kolejowego w zależności od typu oddziaływania

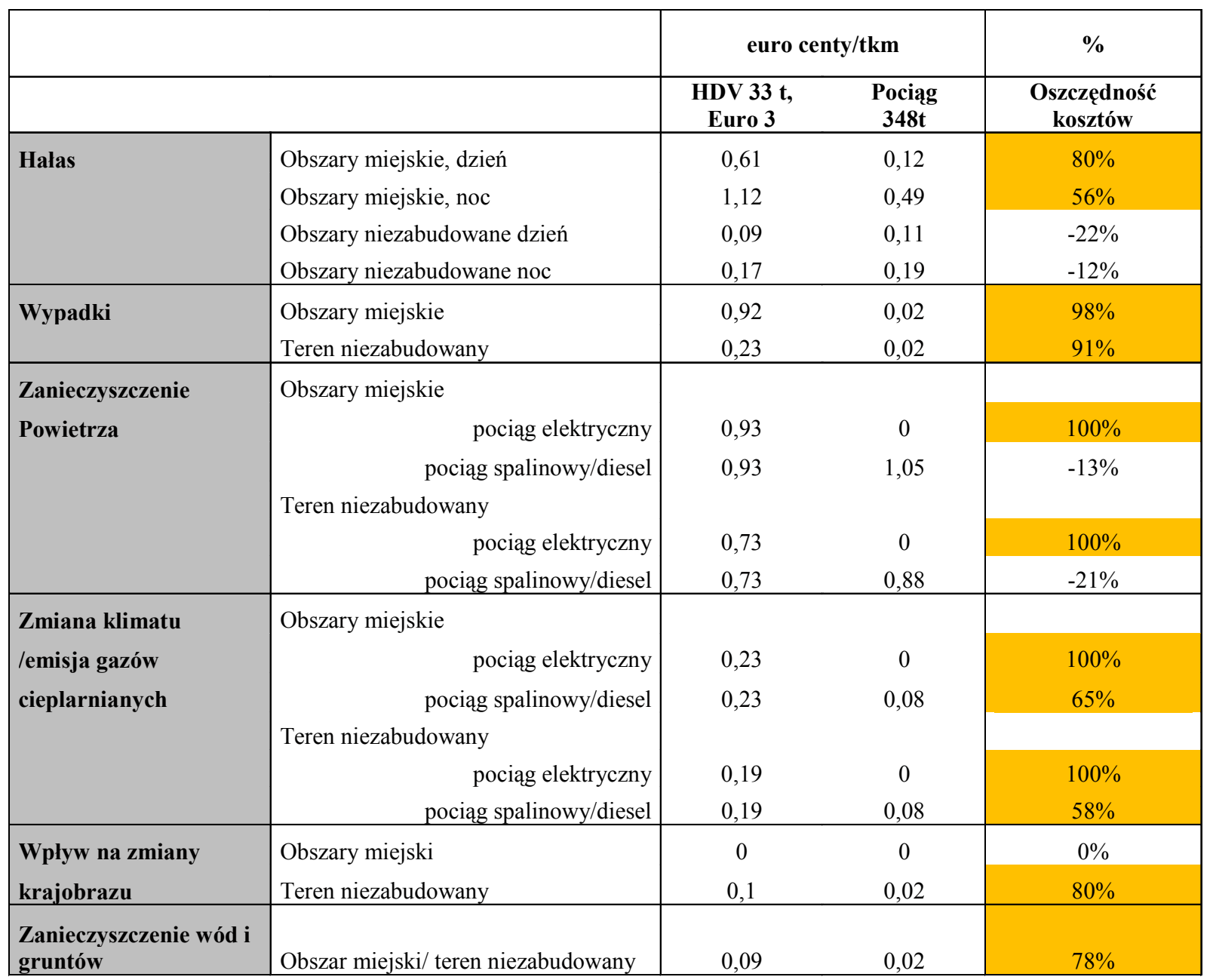

oddziaływania transportu ładunków na środowisko. Dominujący w strukturze przewozu ładunków transport drogowy generuje największe obciążenia środowiskowe. Jeżeli skutki oddziaływań wyrazimy w pieniądzu jako koszty, które ponosi społeczeństwo $\mathrm{w}$ związu $\mathrm{z}$ degradacją środowiska, to koszt generowany przez transport samochodowy wyniesie 10,77 euro/1000 tkm [4]. Koszt generowany przez transport kolejowy jest o $28 \%$ niższy i wynosi 7,75 euro. Natomiast koszty zewnętrzne żeglugi śródlądowej są ponad 3,5-krotnie niższe, a żeglugi bliskiego zasięgu ponad pięciokrotnie niższe. Poszczególne kategorie kosztów dla powyższych gałęzi transportu wskazane zostały w tabeli 1 .
Źródto: Opracowanie wtasne na podstawie Handbook on estimation of external costs in the transport sector, Produced within the study Internalisation Measures and Policies for All external Cost of Transport (IMPACT),Version 1.1, CE Delft, 2008.

Oszczędność kosztów środowiskowych jaką można uzyskać wykorzystując transport kolejowy jest największa w obszarze wpływu na zdrowie i życie ludzkie (wypadki) oraz na zanieczyszczenie powietrza i emisję gazów cieplarnianych przy założeniu wykorzystywania pociagów elektrycznych. Bardziej niekorzystne oddziaływania porównując transport kolejowy z drogowym uzyskano w obszarach ,hałas w terenie niezabudowanym” oraz ,zanieczyszczenie powietrza” przy założeniu wykorzystania lokomotyw spalino- 


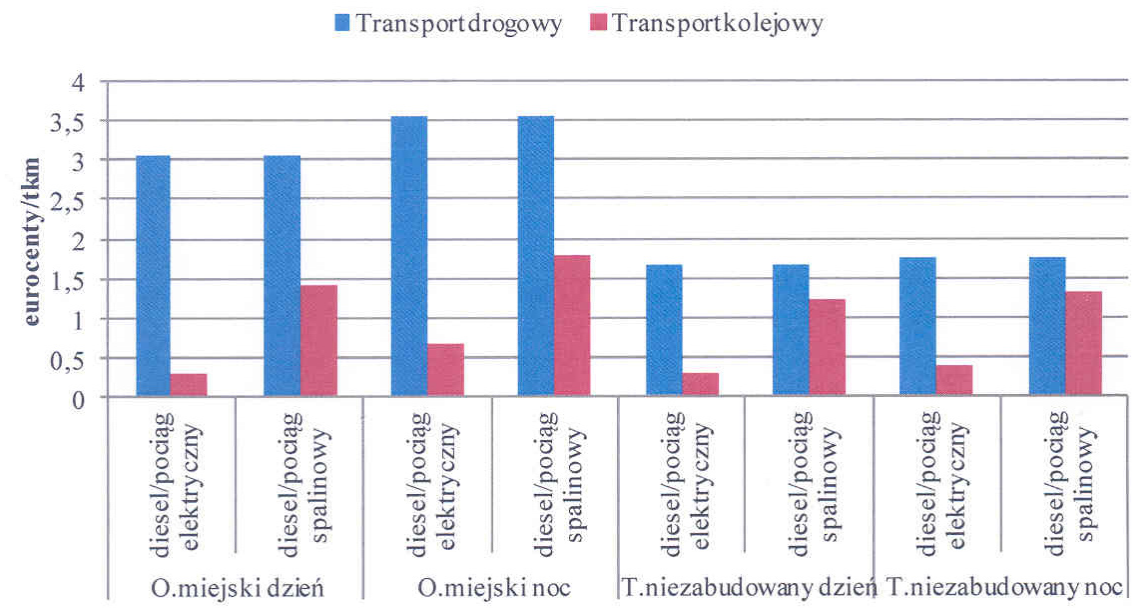

Rysunek 1. Sumaryczne oddziaływania transportu drogowego $i$ kolejowego dla obszarów miejskich i terenów niezabudowanych Źródto: Opracowanie wtasne na podstawie Handbook on estimation of external costs in the transport sector, Produced within the study Internalisation Measures and Policies for All external Cost of Transport (IMPACT),Version 1.1, CE Delft, 2008.

wych. Jednak sumując oddziaływania $\mathrm{z}$ wymienionych w tabeli 2 sześciu grup dla obszarów miejskich i niezabudowanych dodatkowo $\mathrm{w}$ podziale na dzień $\mathrm{i}$ noc, okazuje się, że w każdym przypadku sumaryczne oddziaływania transportu kolejowego są niższe od transportu drogowego i to niezależnie od tego czy wykorzystywane są lokomotywy spalinowe czy elektryczne (rysunek 1).

Sumaryczny koszt oddziaływań środowiskowych wynosi dla transportu drogowego 1,66 eurocenta/tkm $\mathrm{w}$ ciagu dnia $\mathrm{w}$ terenie niezabudowanym do 3,55 eurocenta/tkm w nocy w obszarze miejskim. Dla przewozów kolejowych oddziaływania kształtują się $\mathrm{w}$ granicach od 0,29 eurocenta/tkm w obszarze miejskim w ciagu dnia w przypadku wykorzystywania lokomotyw elektrycznych do 1,77 eurocenta/tkm w obszarze miejskim w nocy w przypadku wykorzystywania lokomotyw spalinowych (por. tabela 3).

\section{Koszty społeczne}

Przeniesienie ładunków z transportu drogowego na transport kolejowy powoduje zmniejszenie potoku ruchu na drogach, co jest bezpośrednio przyczyną zmniejszenia kongestii w niektórych węzłach komunikacyjnych. Zmniejszenie tejże kongestii może w pozytywny sposób wpłynąc na skrócenie traconego czasu, zwiększenie niezawodności dostaw, a także zużycie paliwa. Warto jednakże zauważyć, iż jednocześnie przyczynia się to do wzrostu zatłoczenia na szlakach kolejowych, w którym to przypadku także można mówić o kosztach kongestii związanych np. z ograniczoną dostępnością slotów [5].

Tabela 4 przedstawia koszty wypadków oraz kongestii $\mathrm{w}$ systemach transportowych generowane przez różne gałęzie transportu. Transport drogowy generuje największe koszty, natomiast bezkonkurencyjny w
Tabela 3. Porównanie sumarycznych negatywnych oddziaływań środowiskowych transportu drogowego i kolejowego

\begin{tabular}{|l|c|c|}
\hline & $\begin{array}{c}\text { Transport } \\
\text { drogowy }\end{array}$ & $\begin{array}{c}\text { Transport } \\
\text { kolejowy }\end{array}$ \\
\cline { 2 - 3 } & $\begin{array}{c}\text { eurocenty } \\
\text { /tkm }\end{array}$ & $\begin{array}{c}\text { eurocenty } \\
\text { /tkm }\end{array}$ \\
\hline Obszar miejski dzień: & 3,04 & 0,29 \\
\hline diesel/pociagg elektryczny & 3,04 & 1,4 \\
\hline diesel/pociagg spalinowy & & \\
\hline Obszar miejski noc: & 3,55 & 0,66 \\
\hline diesel/pociagg elektryczny & 3,55 & 1,77 \\
\hline diesel/pociagg spalinowy & & \\
\hline $\begin{array}{l}\text { Teren niezabudowany } \\
\text { dzień: }\end{array}$ & 1,66 & 0,31 \\
\hline diesel/pociag elektryczny & 1,66 & 1,24 \\
\hline diesel/pociagg spalinowy & & \\
\hline Teren niezabudowany noc: & 1,74 & 0,39 \\
\hline diesel/pociagg elektryczny & 1,74 & 1,32 \\
\hline diesel/pociagg spalinowy & & \\
\hline
\end{tabular}

Źródto: Handbook on estimation of external costs in the transport sector, Produced within the study Internalisation Measures and Policies for All external Cost of Transport (IMPACT), Version 1.1, CE Delft, 2008.

tym zestawieniu jest transport wodny, który praktycznie nie generuje żadnych kosztów.

$\mathrm{W}$ związku z większym bezpieczeństwem transportu szynowego, przeniesienie przewozów na tę gałąź skutkuje zmniejszeniem liczby wypadków. Wykorzystanie transportu kolejowego pozwala na obniżenie kosztów wypadków o 73\%. Jeszcze większe korzyści można zauważyć z punktu widzenia kosztów kongestii, które dla transportu kolejowego są o blisko $96 \%$ niższe niż dla transportu drogowego. Sumarycznie, z punktu widzenia kosztów społecznych wykorzystanie transportu kolejowego daje oszczędność kosztów na poziomie $83 \%$. 
Tabela 4. Koszty społeczne generowane przez wypadki oraz kongestię w różnych galęziach transportu

\begin{tabular}{|l|c|c|c|c|}
\hline [euro/1000 tkm] & $\begin{array}{c}\text { Transport } \\
\text { samocho- } \\
\text { dowy }\end{array}$ & $\begin{array}{c}\text { Transport } \\
\text { kolejowy }\end{array}$ & $\begin{array}{c}\text { Żegluga } \\
\text { śródlądo- } \\
\text { wa }\end{array}$ & $\begin{array}{c}\text { Żegluga bli- } \\
\text { skiego zasięgu }\end{array}$ \\
\hline Wypadki & 5,44 & 1,46 & 0 & 0 \\
Koszty kongestii & 5,45 & 0,235 & nieistotne & nieistotne \\
Suma & $\mathbf{9 , 9 9}$ & $\mathbf{1 , 6 9 5}$ & minimalne & minimalne \\
\hline
\end{tabular}

Źródto: European Commission, Commission calculation of the external cost savings according to Article 5(3)of the draft Regulation, 2002

\section{Inne koszty zewnętrzne}

Przedstawione powyżej rozważania dotyczyły stosunkowo najlepiej rozpoznanych w literaturze rodzajów kosztów zewnętrznych. W literaturze przedmiotu $[1,5,6,8]$ wskazuje się jednakże na potencjalne inne oddziaływania mogące generować koszty zewnętrzne. Kosztom tym jednakże częstokroć trudno jest przypisać jakąkolwiek wartość pieniężna.

Jeden z takiego rodzaju kosztów wynika z oddziaływania na abiotyczne zasoby naturalne. $\mathrm{W}$ przypadku transportu koszt ten dotyczy przede wszystkim zużycia zasobów stanowiących źródła energii nieodnawialnej (ropa naftowa, gaz ziemny). Fridell i in. [5] wskazali wysokość tego kosztu na 0,022-0,221 euro/kg, przy najbardziej prawdopodobnej wartości wynoszącej 0,104 euro/kg. Przy czym warto zauważyć, że ostateczna wysokość tego kosztu uzależniona jest od poziomu udziału surowców odnawialnych w paliwach, a w przypadku stosowania lokomotyw elektrycznych miksu energetycznego pozyskiwanego $\mathrm{z}$ sieci prądu.

Ważnym oddziaływaniem społecznym, generującym koszty zewnętrzne, jest również tzw. odcięcie. Jest ono definiowane, jako występowanie w rzeczywistości lub odczuciu ludzkim barier dla ruchu na danym obszarze, które spowodowane są przez infrastrukturę transportową lub ruch pojazdów [8]. Bariery te maja negatywny wpływ na decyzje odnośnie korzystania $\mathrm{z}$ różnego rodzaju obiektów, a także mogą powodować utrudnienia społecznych interakcji (np. wśród dzieci) [8] oraz zmniejszenie poziomu bezpieczeństwa, zwiększenie przestępczości, czy też powstanie poczucia wykluczenia [1]. Wyróżnia się dwa rodzaje odcięcia, tj.: pierwotne związane $\mathrm{z}$ faktem istnienia fizycznej bariery oraz wtórne, związane jest $\mathrm{z}$ brakiem zastosowania lub zastosowaniem niewystarczających działań mających przeciwdziałać odcięciu pierwotnemu, np. poprzez budowę przejść podziemnych utrudniających ruch osób niepełnosprawnych i rowerzystów, a także nieodpowiedni poziom utrzymania skutkujący oblodzeniem lub podtopieniem/zalaniem, czy też brakiem utrzymania porządku, co z kolei skutkuje zwiększeniem obaw o bezpieczeństwo oraz zniechęceniem pieszych do korzystania $\mathrm{z}$ infrastruktury [8].

Koszty zewnętrzne powstawać mogą także w związku $\mathrm{z}$ wibracjami generowanymi przez transport [8]. Literatura w tym zakresie koncentruje się w dużej części na kwestii wpływu transportu na zabytkowe budynki. Wskazuje się tu, że w dłuższej perspektywie czasu wibracje powodują uszkodzenia budynków. Nawet niewielkie uszkodzenia traktowane mogą być jako znacząco rzutujące na ich wartość [8]. Stąd biorąc pod uwagę nieodwracalność zniszczeń, zasoby historyczne, czy też kulturowe mogą być chronione poprzez wprowadzanie ograniczeń możliwości planowania infrastruktury transportowej w ich sąsiedztwie.

Kolejnym rodzajem kosztów są te wywołane intruzją wizualną infrastruktury [1]. Intruzja ta może przyczynić się do „zniszczeń scenerii”, a co za tym idzie obniżenia wartości sąsiadujących zasobów historycznych, kulturowych, czy też rekreacyjnych [1]. Dostępna na ten temat literatura koncentruje się w głównej mierze na transporcie drogowym, przy bardzo niewielkiej liczbie prac dotyczących innych gałęzi transportu [8]. Jakość wizualna może być w szczególności obniżona przez fakt instalowania ekranów akustycznych oddzielających analizowaną infrastrukturę od sąsiadujących działek w celu zmniejszenia negatywnego oddziaływania hałasu [9]. W tym przypadku wskazuje się [8] na narastający trend przedkładania aspektów estetycznych ponad aspekty zdrowotne związane $\mathrm{z}$ podwyższonym poziomem hałasu.

Oprócz powyższych w literaturze wskazywane są także kwestie zakłóceń elektromagnetycznych [6].

\section{Podsumowanie}

Dzięki rozwojowi transportu szynowego (w tym multimodalnego) polepsza się perspektywa rozwoju rynków globalnych. W przypadku Polski daje to możliwość umocnienia kraju na pozycji łącznika między Europą Zachodnią a Europą Wschodnią oraz Rosją. Z punktu widzenia klientów usług transportowych na dalekich trasach transport szynowy może przynosić wymierne oszczędności. Najważniejsze jednak korzyści ekonomiczne transport szynowy generuje na poziomie makroekonomicznym, w szerokim ujęciu społeczno-gospodarczym. Korzyści te wyrażają się oszczędnościami związanymi ze zmniejszonymi kosztami zewnętrznymi oraz kosztami tworzenia infrastruktury.

Tabela 5 przedstawia całkowity rozkład kosztów, jakie należy ponieść na 1000 tkm w zależności od gałęzi transportu. Natomiast rysunek 2 pokazuje poziom oszczędności generowany w stosunku do transportu drogowego. Widać wyraźnie, że transport drogowy generuje koszty dwa razy większe w porównaniu do transportu kolejowego, a pięć i sześć razy większe w porównaniu do transportu wodnego. 
Tabela 5. Koszty globalne generowane przez różne galęzie transportu

\begin{tabular}{|l|c|c|c|c|}
\hline \multicolumn{1}{|c|}{ [euro/1000 tkm] } & $\begin{array}{c}\text { Transport samochodo- } \\
\text { wy }\end{array}$ & $\begin{array}{c}\text { Transport kolejo- } \\
\text { wy }\end{array}$ & Żegluga śródlądowa & $\begin{array}{c}\text { Źegluga bliskiego } \\
\text { zasięgu }\end{array}$ \\
\hline Wypadki & 5,44 & 1,46 & 0 & 0 \\
\hline Poziom hałasu & 2,138 & 3,45 & 0 & 0 \\
\hline Emisja zanieczyszczeń & 7,85 & 3,8 & 3 & nieistotne \\
\hline $\begin{array}{l}\text { Emisja gazów cieplarnia- } \\
\text { nych }\end{array}$ & 0,79 & 0,5 & nieistotne & $<1$ \\
\hline Infrastruktura & 2,45 & 2,9 & 1 & nieistotne \\
\hline Koszty kongestii & 5,45 & 0,235 & nieistotne & około 3,0 \\
\hline Suma & $\mathbf{2 4 , 1 2}$ & $\mathbf{1 2 , 3 5}$ & około 4,0 & (2, \\
\hline
\end{tabular}

Źródlo: European Commission, Commission calculation of the external cost savings according to Article 5(3)of the draft Regulation, 2002

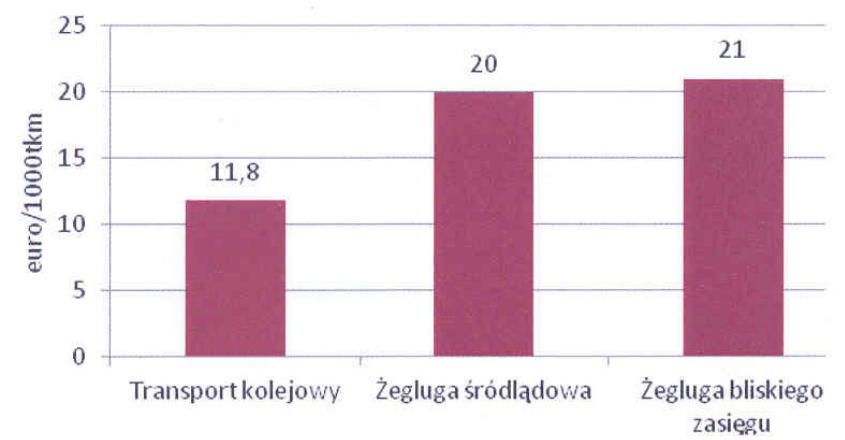

Rysunek 2. Oszczędności wynikajace ze zmiany gatęzi transportowej i przeniesieniem ładunków z transportu drogowego na inne gatęzie transportu[euro/1000tkm]

Źródto: European Commission, Commission calculation of the external cost savings according to Article 5(3) of the draft Regulation, 2002

\section{Bibliografia}

[1] Annema J., Koopmans C., The practice of valuing the environment in cost-benefit analyses in transport and spatial projects, Journal of Environmental Planning and Management, 2014 (w druku, DOI:10.1080/09640568.2014.941975)

[2] Damart S., Roy B., The uses of cost-bene?t analysis in public transportation decision-making in France, Transport Policy, vol. 16, 2009, s. 200-212
[3] De Brucker K., Macharis C., Verbeke A., Multicriteria analysis and the resolution of sustainable development dilemmas: A stakeholder management approach, European Journal of Operational Research, vol. 224, 2013, s. 122-131

[4] European Commission, Commission calculation of the external cost savings according to Article 5(3)of the draft Regulation, 2002

[5] Fridell E., Belhaj M., Wolf C., Jerksjö M., Calculation of external costs for freight transport, Transportation Planning and Technology, vol. 34, nr 5, s. 413-432

[6] Griškevičiūtè-Gečienè A., Burinskienè M., Towards creating the assessment methodology for urban road transport development projects, Technological and Economic Development of Economy, vol. 18, $\mathrm{nr} 4$, 2012, s. 651-671

[7] Handbook on estimation of external costs in the transport sector, Produced within the study Internalisation Measures and Policies for All external Cost of Transport (IMPACT),Version 1.1, CE Delft, 2008

[8] Markovich J., Lucas K., The Social and Distributional Impacts of Transport: A Literature Review. Transport Studies Unit, School of Geography and the Environment, Working Paper $N^{\circ} 1055$, Sierpień 2011, Oksford

[9] Zmuda-Trzebiatowski P., Bieńczak M., Kiciński M., Fierek S., Żak J., Wielokryterialna ocena wariantów przebudowy skrzyżowania z ruchem okrężnym na przykładzie modernizacji Ronda Rataje w Poznaniu, Technika Transportu Szynowego, nr 9, 2012, cd, s. 4585-4594 